\title{
超臨界流体抽出の食品への応用
}

\author{
小林猛 \\ 名古屋大学工学部化学工学科 (名古屋市千種区不老町)
}

\section{Application of Supercritical Fluid Extraction for Food Processing}

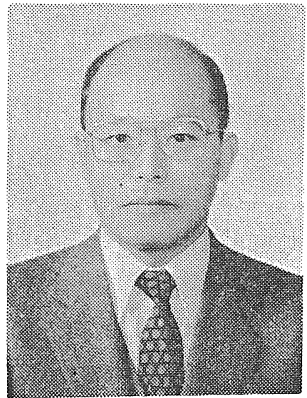

Takeshi KовAYAshi

Department of Chemical Engineering, Faculty of Engineering, Nagoya University

(Furocho, Chikusa-ku, Nagoya)

\section{1 はじめに}

抽出操作では，最適な溶郕の選定が重要であり，次の ような基準で選ばれることが多い。つまり，目的成分の 溶解度が大きく, かつ選択的に抽出すること, 原料との 密度差が大きく，エマルション化しにくいこと，目的成 分との沸点差が大きくて，共沸混合物を生じないこと， 化学的に安定で, 毒性や腐食性がないこと, 蒸発潜熱や 比熱が低く，粘度も低いこと，などである。超臨界流体 抽出でも同じように最適な超臨界流体の選定が極めて重 要である。

超臨界流体として現在までよく用いられてきた物質は エタン, エチレン, プロパン, 亜酸化窒素, 二酸化炭素等 である。これらの物質の中で, 二酸化炭素は 1) 臨界温 度が $31.1^{\circ} \mathrm{C}$, 臨界圧力が $73 \mathrm{~atm}$ であり, 比較的常温に 近い臨界温度であるので，熱に不安定な物質等の抽出に も適用可能である，2）不活性ガスであるため引火性， 化学反応性がなく，また残存した場合にも人体に対して 無害である，3）安価で, 純度の高いガスの入手が容易 であったり，発酵プロセスで発生する場合にはそれを利 用しうる，等々の長所があり，最むよく利用されてい る。食品工業に抒いて最も重要なことは「食品の安全 性」であるので, 超臨界流体抽出に用いられる溶剤とし ては二酸化炭素が最も適している。しかし, 脂溶性物質 の溶解度といら点ではエタン, プロパンなどより劣る。 この点を改善するために, 被抽出物質と親和力の強い物 質（エントレーナー）を二酸化炭素に添加することもあ る。エントレーナーとしては, エタノール, 酢酸, 水な どが使われる。

食品素材から有機溶剤を用いて特定の物質を抽出する 操作は広く行われ，ヘキサン，ジクロロメタン，メタ， ール，エチルアセテートなどが主として使用されてき た。しかし，目的成分のみが抽出されるとは限らないの で, 精製工程が必要な場合が多く，また有機溶㓮が残留
する可能性も問題となる。これに対して二酸化炭素によ る超臨界流体抽出の場合には, 目的成分の他に別の成分 も抽出されるとしても, 数段の減圧分離によって異なっ た組成の抽出物の選択分離が可能である。また, 溶剤で ある二酸化炭素の残留も全く問題にならない。

実際に食品の処理として考えられる対象としては，a） 香料，スパイスの処理，b) 特定成分（カフェインなど） の抽出, c) 脱臭, 脱色などである。現在, 実用段階の応 用例としては，コーヒー豆の脱カフェイン及びホップ成 分の抽出がある。また，パイロットプラントの段階の例 としては, 植物油の抽出, エタノールの濃縮, フレーバー の抽出, レシチンの精製, 魚油成分の分画などがある。

以下, 実際に検討されている食品分野での代表的な応 用例について紹介する。

\section{2 コーヒーの脱カフェイン}

超臨界二酸化炭素を用いたプラントが西ドイッの HA $\mathrm{G}$ 社で 1978 年より稼動し, $40 \mathrm{~m}^{3}$ の抽出槽 4 基で年間 20 万 $\mathrm{t}$ 処理されている。抽出は水を含有したグリーン コーヒー豆を用いて行われる。コーヒー豆が乾燥した状 態で抽出すると，図-1 に示すようにカフェインよりも 香り成分が先に抽出されてしまう。しかし，水が存在す ると香り成分は抽出されず，カフェインがまず抽出され る。したがって，水の存在はカフェインの選択的抽出の ためには不可欠である ${ }^{1)}$ 。図-2 は超臨界二酸化炭素中に

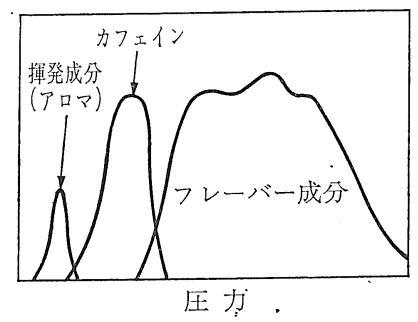

図-1 コーヒーの抽出成分 

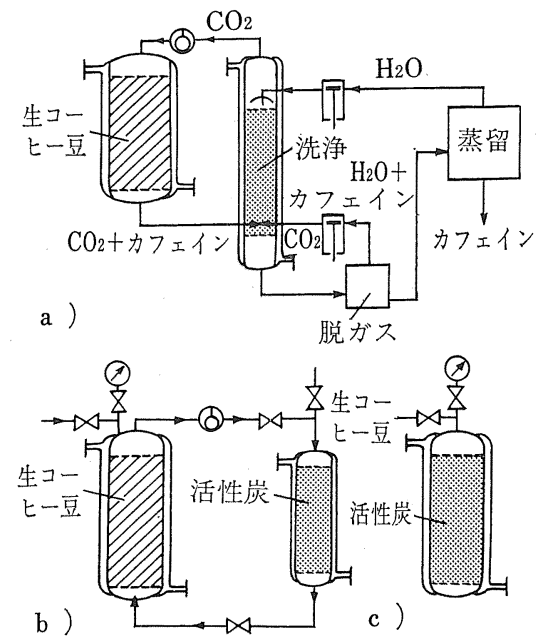

図-2 カフェインの分離方法

抽出されたカフェインを分離する方法を示す22。a）はカ フェインを含む超臨界二酸化炭素を $70 \sim 90^{\circ} \mathrm{C}$ の水で洗 浄し, 洗浄水へ移行したカフェインを脱ガス後, 蒸留に よって回収する方法である。9 $90^{\circ} \mathrm{C} て ゙ ~ 10 \mathrm{~h}$ の運転で全 カフェインが水層へ移り, 豆中のカフェイン含有量は原 料中の $0.7 \sim 3 \%$ から $0.02 \%$ 以下に低減される。b）は 活性炭を用いてカフェインを吸着分離する方法で，この 場合には活性炭からカフェインを分離する操作が必要と なる。c) は抽出器中にコーヒー豆と活性炭粒子の混合 物を入れてカフェインを除去する方法である。

なお，紅茶のカフェイン除去も同様に行われる。

\section{3 ホップの抽出}

ホップはビールに特有の爽快さ，苦味，香気を与える 植物であり，その有効成分は揮発性油とソフトレジンと 総称される物質である。雌のホップの花が成熟すると, 葉の間や軸の周りにうろこ状のルプリン粒ができる。こ れには $\alpha$ 酸と $\beta$ 酸（これらを総称してソフトレジンと いう), 揮発性油, タンニン, 樹脂成分が含まれている。 ソフトレジンは, ホップからエーテル抽出によって得ら れるものをさし，これがビール特有の苦味を出す重要な 役割をはたしている。また，非極性溶剤に不溶な樹脂分 はハードレジンと呼ばれ，ホップの収穫後時間が経つに つれてソフトレジンからハードレジンへと転換する。ホ ップエキスは従来ジクロロメタンにより抽出されてきた が, 抽出物はペースト状の暗緑色, 黒緑色物質で, 不純 物も多く, 脱溶媒の必要もある。

ホップの有効成分を抽出する方法として液体二酸化炭 素を用いる方法と超臨界二酸化炭素を用いる方法が報告

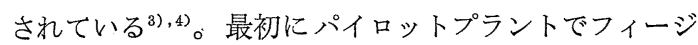
ビリティスタディがなされ，その有效性が確認されてか

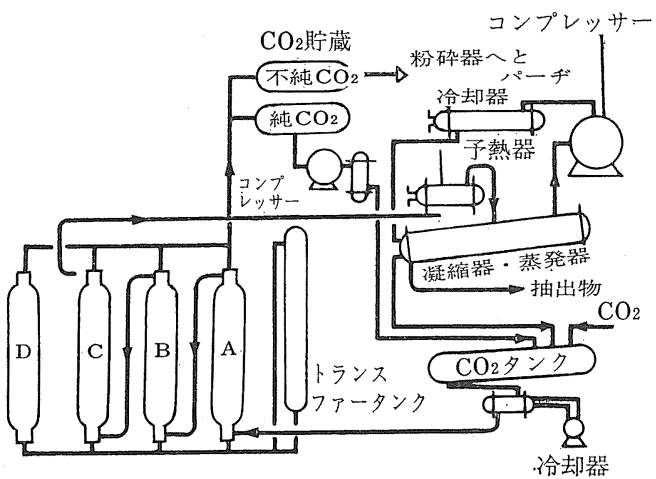

図-3 液体二酸化炭素によるホップの抽出

表-1 ホップの分析例

\begin{tabular}{|c|c|c|c|c|c|}
\hline 成 & 原 料 & 抽残物 & 抽出液 & 抽出率 & $\begin{array}{l}\text { 市販の } \\
\text { 抽出液 }\end{array}$ \\
\hline 水 分 $(\%)$ & 6.0 & 5.4 & 7.0 & & 8.0 \\
\hline 全レジン(\%) & 30.3 & 4.3 & 90.0 & 89.9 & 88.5 \\
\hline ソフ上 & 26.6 & 1.3 & 84.8 & 96.5 & 82.0 \\
\hline$\alpha$-酸 $(\%)$ & 12.6 & 0.2 & 41.2 & 98.9 & 39.5 \\
\hline$\beta$-酸 $\quad(\%)$ & 14.0 & 1.1 & 43.6 & 94.4 & 42.5 \\
\hline ハジジ $(\%)$ & 3.7 & 3.0 & 5.2 & & 6.5 \\
\hline
\end{tabular}

ら $6.5 \mathrm{~m}^{3}$ の抽出槽をもつ本プラントが建設されて 1982 年 10 月から稼動し, 年間処理量は $5,000 \mathrm{t}$ の能力がある。 前処理として，ルプリン粒を破壞して二酸化炭素のよ うな非極性溶剤が浸透しやすいようにする必要がある。 最初のミルで粗砕したのちペレット圧搾機によって押出 せん断加工する。温度が上昇するのでクーラーを通して 冷却し，二番目のミルでペレットを粉砕する。図-3 は 液体二酸化炭素を用いる抽出装置のフローを示す。おの おのが 500 600 kg のホップを充てんできる大きさで， 3 基は常に連結されており，7 10 $\mathrm{C}$ の温度で向流抽出 される。

表-1 は分析結果である。抽出物の色はオリブグリーン であり,ソフトレジンの構成成分である๙酸は $99 \%$ 程度 抽出され，ハードレジンは $20 \%$ 程度しか抽出されない ${ }^{3)}$ 。また, 農薬も抽出されない。芳香成分は抽出中に酸 化を受けず,原料中と抽出物中で全く同じ状態であった。

\section{4 植物油の抽出}

種子からの植物油の抽出は圧䇽法及び溶媒抽出法が害 施されているが, 前者は油脂の回収率, 後者は使用する 溶媒の回収に問題がある。液体二酸化炭素または超臨界 二酸化炭素を用いる油脂の抽出が，ヘキサンを用いる溶 媒抽出と比較しながら各種の植物種子について検討され ているらっ。なかでも，大豆からの食用油の抽出はその処 理規模の大きさや抽出残分を大豆タンパクとして利用す るという観点から注目を集めている。超臨界二酸化炭素 抽出に抢ける大豆油の収率は, 抽出圧力と温度, 大豆の 
图-4 大豆油の溶解度

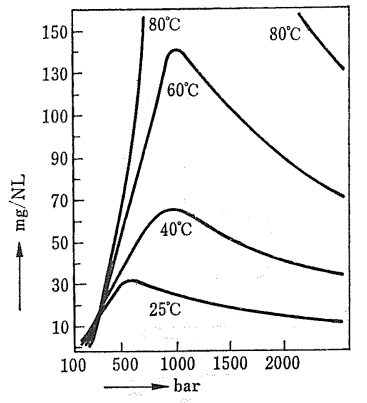

形状, 前処理方法, 水分 含量等により大きく影響 されることが知られてい る。図-4 は大豆油の液 体及び超臨界二酸化炭素 への溶解度を示す ${ }^{6)}$ 。 $350 \mathrm{~atm}$ 以下では液体二 酸化炭素への溶解度が高 く, $350 \mathrm{~atm}$ 以上では超 臨界二酸化炭素への溶解 度が高くなっており，

600 1,000 atm に溶解度の極大值がある。

大豆油抽出における原料中の水分の影響については, コーヒー豆からのカフェインの抽出とは違って, 水分が あると大豆油は抽出されにくくなる7 。原料粒径も抽出 速度に大きな影響を及ぼす7”。有機溶剤を用いて抽出す る場合も，原料粒径が大きくなると抽出速度は低下する ことが知られているが, 超臨界流体抽出の場合も同様の 現象が認められ，原料を前もって圧偏粉砕する必要があ る。

図-5 は小麦はい芽からの油の抽出結果の一例で8), 液 体二酸化炭素を用いた方が低い圧力で抽出できた。ここ で, 抽出量はエーテルで $16 \mathrm{~h}$ ソックスレー抽出した時 に得られる量を 100\% として示している。また, 赤ぬか

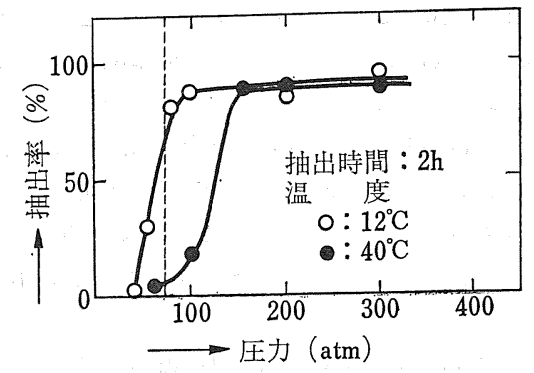

図-5 小麦はい芽油の抽出
を試料として同様の実験を行ったが，小麦はい芽と比較 して同一の抽出率を得るには，より高い抽出圧力または 多くの二酸化炭素が必要であった。

抽出圧力 $20.0 \mathrm{~atm}$, 温度 $40^{\circ} \mathrm{C}$, 抽出時間 $2 \mathrm{~h}$ の条件下 で超臨界二酸化炭素により抽出した小麦はい芽油とクロ ロホルムーメタノール混液またはへキサンによる抽出油 の一般的性質とトコフェロール含量を比較した ${ }^{8)}$ 。表-2 はケイ酸カラムを用いた吸着クロマトグラフィーにより 大まかな分画を行った結果を示している。クロロホルム 溶出画分はすべての中性脂質とわずかの複合脂質を，ア セトン溶出画分は大部分の糖脂質と小量のリン脂質を, メタノール溶出画分はほとんどのリン脂質と微量の糖脂 質をそれぞれ含んでいることがわかっている。表-2 り超臨界二酸化炭素による抽出油は複合脂質をほとんど 含んでいないことが明らかとなった。この結果は薄層ク ロマトグラフィーによっても確認した。

表-3 は，同様の方法で抽出した 3 種類のはい芽油に ついて一般的な特性を比較した結果である。不飽和結合 の含有割合を示すョウ素価及びエステル型脂質の平均分 子量の大きさの指標となるけん化価については, 三者の 閒に大きな差は認められなかった。しかし，超臨界抽出 油のリン含量はクロロホルムーメタノール混液抽出油, ヘキサン抽出油のそれと比較して，それぞれ約 $1 / 40$, 約 1/20 と低く, 着色度も超臨界抽出油は低い值をしめ した。このように, 超臨界二酸化炭素による抽出法で は, ヘキサンによる抽出法では必要であった脱ガム, 脱 色, 脱臭工程が省略できる可能性が高い。また, 超臨界 抽出油にはへキサン抽出油とほぼ同量の $\alpha$ - 及び $\beta$-ト コフェロールが含まれていた。

月見草種子からの油の抽出も同様に行いらる。月見草 種子油はリノール酸を多く含み, rーリノレン酸も約 $7 \%$ 含まれているので注目されている。種子を圧偏粉砕して から, ヘキサン抽出, 超臨界二酸化炭素抽出 (超臨界 $\mathrm{CO}_{2}$ ) 及び液化二酸化炭素抽出（液化 $\mathrm{CO}_{2}$ ) を行った。

表-2 ケイ酸カラムクロマトグラフィーによる小麦はい芽油の分画

\begin{tabular}{|c|c|c|c|c|c|}
\hline 出 & 法 & $\begin{array}{l}\text { クロ车ルム } \\
\text { 溶出画 分 } \\
\text { (mg/100 mg) }\end{array}$ & $\begin{array}{l}\text { ア 艺蓉 } \\
\text { (mg/100 mg) }\end{array}$ & $\begin{array}{l}\text { メ多ール } \\
\text { 溶出画 分 } \\
(\mathrm{mg} / 100 \mathrm{mg})\end{array}$ & $\begin{array}{c}\text { クロマトグラフ } \\
\text { イー後の回收率 } \\
(\%)\end{array}$ \\
\hline $\begin{array}{c}\text { クロロホルムーメタノール } \\
n \text {-ヘキサン } \\
\text { 超臨界 } \mathrm{CO}_{2}\end{array}$ & $\begin{array}{c}65^{\circ} \mathrm{C}, 1.5 \mathrm{~h} \\
\text { ソックスレー, } 16 \mathrm{~h} \\
20 \mathrm{MPa}, 40^{\circ} \mathrm{C}, 2 \mathrm{~h}\end{array}$ & $\begin{array}{l}92.6 \\
95.4 \\
98.7\end{array}$ & $\begin{array}{r}3.4 \\
1.2 \\
\text { 微量 }\end{array}$ & $\begin{array}{r}2.1 \\
\text { 微量 } \\
\text { 微量 }\end{array}$ & $\begin{array}{l}99.1 \\
96.6 \\
98.7\end{array}$ \\
\hline
\end{tabular}

表-3 小麦はい芽油の一般的性質の比較

\begin{tabular}{|c|c|c|c|c|c|c|}
\hline 抽 出 方 法 & $\begin{array}{c}\text { けん化価 } \\
(\mathrm{mg})\end{array}$ & $\begin{array}{c}\text { ヨウ素価 } \\
\text { (g) }\end{array}$ & $\begin{array}{l}\text { リ ン } \\
(\mu \mathrm{g} / \mathrm{g})\end{array}$ & 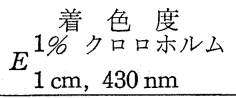 & 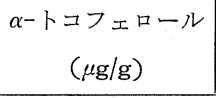 & 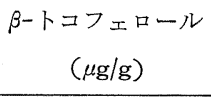 \\
\hline クロロホルムーメタノール & 183 & 116 & 1,270 & 0.157 & 586 & 1,261 \\
\hline ヘキサン & 182 & 127 & 639 & 6.166 & 1,628 & 1,122 \\
\hline 超臨界 $\mathrm{CO}_{2}$ & 176 & 130 & 30 & 0.088 & 1,678 & 1,129 \\
\hline
\end{tabular}


表-4 月見草抽出油の一般的性質の比較

\begin{tabular}{|c|c|c|c|}
\hline 抽 出 方 法 & 液 $\mathrm{CO}_{2}{ }^{\text {化 }}$ & 超 $\mathrm{C}_{\mathrm{CO}_{2}}{ }^{\text {界 }}$ & ヘキサン \\
\hline リン脂質 $(\mathrm{mg} / 100 \mathrm{~g})$ & $<10$ & $<10$ & 70.4 \\
\hline 酸 & 4.24 & 5.83 & 1.24 \\
\hline ヨウ素価 & 155 & 154 & 153 \\
\hline けん化価 & 193 & 192 & 193 \\
\hline$(\mathrm{R} / \mathrm{r})$ & $1.3 / 20.0$ & $1.7 / 20.0$ & $1.6 / 20.0$ \\
\hline 脂肪酸組成 & & & \\
\hline $\mathrm{C}_{16: 0}(\%)$ & 6.45 & 6.53 & 6.57 \\
\hline $\mathrm{C}_{18: 1}(\%)$ & 11.21 & 11.25 & 11.42 \\
\hline $\mathrm{C}_{18: 2}(\%)$ & 74.50 & 74.52 & 74.22 \\
\hline $\mathrm{C}_{18: 3}(\%)$ & 7.85 & 7.70 & 7.80 \\
\hline
\end{tabular}

これらの抽出油の分析結果を表-4 に示す ${ }^{9)}$ 。超臨界 $\mathrm{CO}_{2}$ 抽出油と液化 $\mathrm{CO}_{2}$ 抽出油とはほとんど同じで, へ キサン抽出油と比較してリン脂質含量が低く, 酸価が高 かった。

辛子種子から油脂を除去して幸子として使用するため には, ヘキサンのような溶媒抽出は利用不可能で, 現在 は圧搾法によっている。しかし, 油脂の除去率を高めよ うとすると辛子の品温が高くなり，辛味成分前駆体であ るシニグリンをアリルイソチオシアネートに変換するミ ロシナーゼが失活しやすくなる。そこで, 超臨界二酸化 炭素で抽出した。ミロシナーゼ活性は全く低下せず，油 脂も順調に抽出された ${ }^{10)}$ 。

このほかハトムギやべニバナから超臨界 $\mathrm{CO}_{2}$ あるい は液化 $\mathrm{CO}_{2}$ で良質な油が抽出されている。

\section{5 エタノールの濃縮}

固定化酵母によるバイオマスからのエタノール生産が 注目されている。この場合, 約 8〜12 wt\% のエタノー

表-5 エタノールの濃縮のためのエネルギー比較

\begin{tabular}{|c|c|c|c|c|c|}
\hline & \multicolumn{5}{|c|}{ 超 臨 界 抽 出 蒸 留 法 } \\
\hline & (1) & (2) & (3) ジレブ & (4) 充てん塔 & (5) 充て \\
\hline エタノール原料 & & 8.1 & $\rightarrow$ & $\rightarrow$ & $\rightarrow$ \\
\hline 組 成 (wt\%) 製 品 & 91 & 94 & $\rightarrow$ & $\rightarrow$ & $\rightarrow$ \\
\hline エネルギー $(\mathrm{kcal} / \mathrm{kg})$ & 865 & 990 & 1,280 & 940 & 430 \\
\hline
\end{tabular}

注）（1）中試験に基ゔく $\mathrm{ADL}$ 社の試算

(2) (5) 平衡デー夕に基づく試算

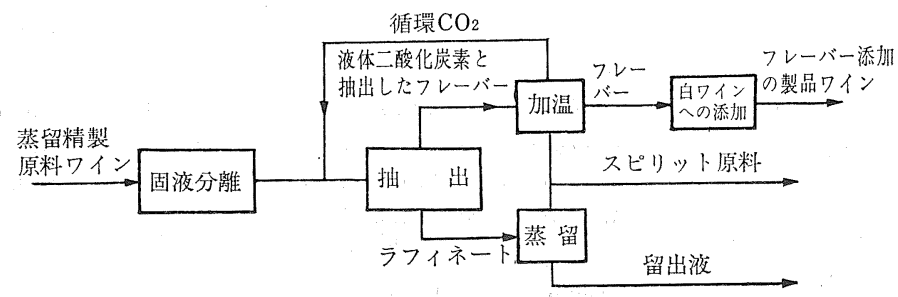

図-6 ワインフレーバーの回収と白ワインへの添加
ル水溶液からどのようにしてエタノールを濃縮するかが 極めて重要で, 通常の蒸留法より超臨界二酸化炭素によ る抽出法の方が省エネルギー的に実施できるかが注目さ れている。表-5 はその試算の一例を示す ${ }^{11)}$ 。この場合, エタノール濃縮液中のフーゼル油や各種のフレーバーの 濃度が通常の蒸留法の場合と比較して, どのように変化 するかも問題となる。

米国 Critical Fluid Systems 社のパイロットテスト によると，エタノール濃度が $2 \sim 15 \mathrm{wt} \%$ の原料から 84 〜 $91 \mathrm{wt} \%$ の製品が得られているが，共沸組成(95.6 $\mathrm{wt} \%$ ）は越えないようである。また，エタノールの分配 係数が約 0.1 と小さいので, 高い回収率を得るにはガ ス/原料比を 15 以上にする必要がある。

また, 各種酒類からのフレーバーの抽出, 各種酒類の 低アルコール化なども興味ある応用例と考えられる。例 えば，ワインを蒸留してブランデーやスピリットを生産 する場合, 蒸留でアルコールを分離する前にフレーバー 成分を液体二酸化炭素を用いて回収することが検討され ている ${ }^{12)}$ 。図-6 に示す工程で回収し，濃縮されたフレ ーバーはワインに添加され，フレーバーを強化したワイ ンが調製されている。

\section{6 脂肪酸エステルなどの分画・濃縮}

イコサペンタエン酸 (EPA) が最近注目されており, これを比較的含有している魚油を分解して脂肪酸をエス テル化し, 脂肪酸エステル混合物の分画を行うことが研 究されている。Eisenbach はホットフィンガー付きの抽 出装置でたら油脂肪酸エチルエステルを $150 \mathrm{~atm}, 50^{\circ} \mathrm{C}$, 分離圧 $25 \mathrm{~atm}$ で 2 回分画操作した ${ }^{13)}$ 。 $\mathrm{C}_{20}$ エステルと して収率 79.8\%，純度 $91.9 \%, E P A$ として収率 77 $\%$ ，純度 $48.2 \%$ となった。

新井らは直鎖脂肪酸エステルが尿 素と包接化合物を作る性質を利用し て, 効率のよい分画が可能である事 を示した ${ }^{14)}$ 。直鎖有機化合物が尿素 と共存すると，尿素分子は 図-7 に 示すように約 $5 \AA$ の真直ぐな空洞 を作り，この中に直鎖化合物を包み 込んで結晶化して析出する。飽和脂 肪酸の分子構造は直鎖状であるので 尿素と包接しやすく, 不飽和脂肪酸 は尿素と包接しにくい。16 g のい わし油脂肪酸メチルエステルと 105 gの尿素を用いて, $40^{\circ} \mathrm{C}, 100 \mathrm{~atm}$ で 超臨界 $\mathrm{CO}_{2}$ 抽出し結果を図-8 に示す。尿素を用いると, 最後まで EPA が濃縮されているのがわか る。包接化合物は温度をあげてやる 


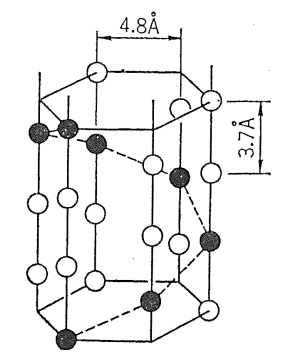

付加化合物を構成する尿素の結晶楧造 六方晶系 $\mathrm{a}=8.20 \sim 8.24 \AA$ $c=11.0 \sim 11.1 \AA$

○は単位格子の 6 原子を表す

図-7 尿素の結晶構造

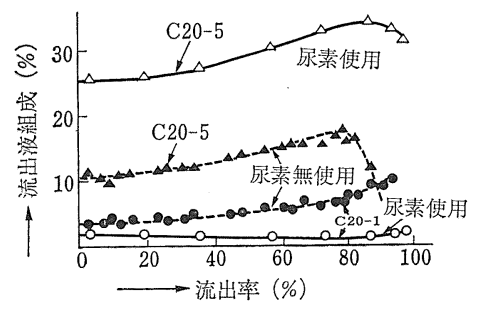

図-8 尿素付加法を利用した $\mathrm{C}_{20}$ メチル エステルの分離

と，尿素と直鎖脂肪酸エステルに分解するので，脂肪酸 エステルを含む超臨界二酸化炭素と尿素微粉末を向流に 接触させ，塔下部に温度こう配を付けた回収部を備えた 装置によって 不飽和脂肪酸を 高収率, 高濃度に分離し うる。この方法はドコサヘキサエン酸 (DHA) の濃縮 にも応用しらる。

大豆レシチンの濃縮にも超臨界 $\mathrm{CO}_{2}$ 抽出は応用され ている。上記したように超臨界 $\mathrm{CO}_{2}$ は中性脂質は抽出 するがリン脂質はほとんど抽出しない。したがって大豆 油精製工程から得られるレシチンを含む画分を，脱水し た後で超臨界 $\mathrm{CO}_{2}$ 抽出するとレシチンが濃縮される。

\section{7 タバコの脱ニコチン}

図-9 に示すプロセスが検討されている ${ }^{32}$ 。まず最初 に, 通常の水分量量 $(10 \sim 13 \%)$ で香り成分を抽出し, つぎに水分含量を $25 \%$ 程度まであげてニコチンを抽出 し, 元の水分含量まで乾燥した後に抽出した香り成分に 戻してやる。このような操作によって $95 \%$ 程度のニコ チンが除去されだ)。

小針ら ${ }^{15)}$ は葉たばこの抽出について詳しく研究した。 $15^{\circ} \mathrm{C}$ での液体 $\mathrm{CO}_{2}$ では, エキスの主成分であるニコチ ン, ネオフィタジェン, ソラネソールのうち, ニコチン の抽出率が低いことがわかった。超臨界 $\mathrm{CO}_{2}$ では抽出 温度の上昇に伴ってニコチンの抽出率が急増した。 た，彼らはゆず，しそ，ジンジャーなど有香動植物を液

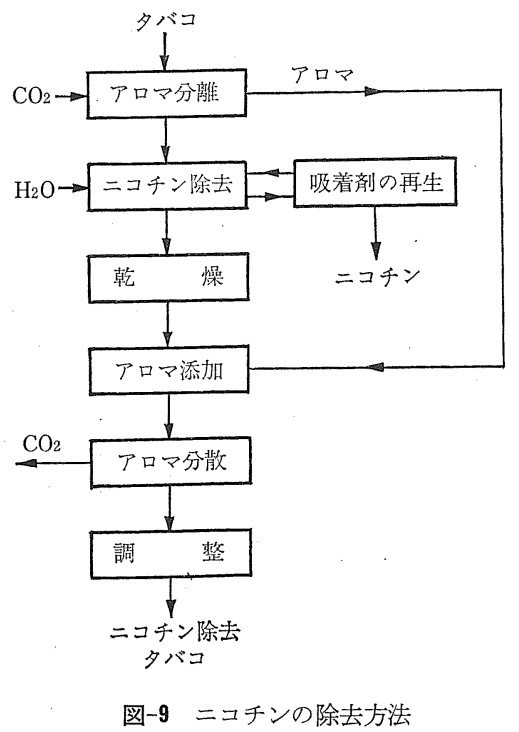

体 $\mathrm{CO}_{2}$ または超臨界 $\mathrm{CO}_{2}$ で抽出し，抽出エキスの特 徵についても研究している。

\section{8 その他の関連分野への応用}

超臨界流体処理は食品や医薬品原料の殺菌にも応用し らるので, 加熱殺菌や薬剂殺菌が難しい場合の新しい殺 菌法として注目される。この場合, 水分含量の影響は大 きく, 表-6 に示すように, 2 10\% の水分含量では殺 菌効果はあまり 期待できない。これに詨して 70〜90\% の水分含量の場合には細菌の内生胞子を除いて, 微生物 及びカビの分生胞子は死滅した ${ }^{16)}$ 。

超臨界流体中の反応も興味ある応用例である。Shim= shick は低級脂肪酸ナトリウム水溶液からの脂肪酸の分

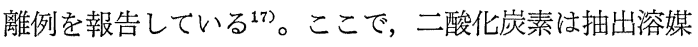
であり，かつ反応物質として作用している。また，超臨 界二酸化炭素を酵素反応の媒体として利用することもで きる。Randolph らは 0.1 vol\% の水を含む超臨界 $\mathrm{CO}_{2}$ 中でアルカリホスファターゼにより p-ニトロフェノー ルが生成することを認めた ${ }^{18)}$ 。中村らもリパーゼによる

表-6 超臨界二酸化炭素処理における殺菌効果

\begin{tabular}{|c|c|c|}
\hline \multirow{2}{*}{ 微 生 物 } & \multicolumn{2}{|c|}{ 生菌数割合 $[-]$} \\
\hline & 湿菌 体* & 乾燥菌体*** \\
\hline パン酵母 & $5.4 \times 10^{-7}$ & 0.50 \\
\hline Escherichia coli & $7.2 \times 10^{-6}$ & 0.047 \\
\hline Staphylococcus aureus & $1.5 \times 10^{-5}$ & 0.037 \\
\hline Aspergillus niger (conidia) & $1.2 \times 60^{-5}$ & 0.88 \\
\hline Bacillus subtilis (endospore) & 0.47 & 0.99 \\
\hline $\begin{array}{r}\text { Bacillus stearothermophilus } \\
\text { (endospore) }\end{array}$ & 1.07 & 0.80 \\
\hline
\end{tabular}

$200 \mathrm{~atm}, 35^{\circ} \mathrm{C}, 2 \mathrm{~h}$ の処理条件

* 水分含量 $70 \sim 90 \%$ ** 水分含量 $2 \sim 10 \%$ 
エステル交換反応を報告しており ${ }^{19)}$, 我々もコレステロ ールエステラーゼやチオグルコシダーゼが超臨界 $\mathrm{CO}_{2}$ 中で作用することを認めている20)。

また，我々は抗生物質精製プロセスの脱溶媒にも応用 しうることを示した ${ }^{21)}$ 。超臨界流体を用いる分離技術は 応用範囲の広い方法であり, 今後はさらに広い範囲に適 用されるようになろう。

（昭和 61 年 1 月 16 日受理）

\section{文献}

1）高橋和郎, 食品工業, 10 月下, 68 (1983)

2) K. Zosel, Angew. Chem. Int. Ed. Engl., 17, 702 (1978)

3) P. Hubert, O.G. Vitzthum, Angew. Chem. Int. Ed. Engl., 17, 710 (1978)

4) D.S. Gardner, Chem. Ind. (London), 1982, 402

5) J.P. Friedrich, E.H. Pryde, J. Am. Oil Chem. Soc., 61, 223 (1984)

6) J.P. Friedrich, G.R. List, J. Agric. Food Chem., 30, 193 (1982)

7）安芸忠徳, フレグランスジャーナル, No. 67, 23 (1984)

8) T. Taniguchi, T. Tsuji, M. Shibata, T. Kobayashi, Agric. Biol. Chem., 49, 2367 (1985)
9）安芸忠徳，化学工学協会関東支部講演会「食品・天然物 の超臨界流体抽出」, 14 (1985)

10）谷口正之, 野村隆治, 上平正道, 小林 猛, 木島 勲, 日本農芸化学会昭和 61 年度大会講演要旨集, 235 (1986)

11）片岡義彦, ファインケミカル，2月15 日, 3 (1984)

12) G. Brunner, S. Peter, Separation Sci. and Technol., 17, 199 (1982)

13) W. Eisenbach, Ber. Bunsenges. Phys. Chem., 88, 882 (1984)

14）新井邦夫, 化学工学協会関東支部講演会「食品 - 天然物 の超臨界流体抽出」, 1 (1985)

15）小針正夫, 米井祥男, 化学工学協会関東支部講演会「食 品・天然物の超臨界流体抽出」, 28 (1985)

16）谷口正之, 上平正道, 小林 猛, 日本農芸化学会昭和 60 年度大会講演要旨集, 621 (1985)

17) E.J. Simshick, Chemtech, 13, 374 (1983)

18) T.W. Randolph, H.W. Blanch, J.M. Prausnitz, C.R. Wilke, Biotech. Lett., 7, 325 (1985)

19）中村厚三, 矢野俊正, 化学工学協会関東支部講演会「食 品・天然物の超臨界流体抽出」, 37 (1985)

20）上平正道, 谷口正之, 野村隆治, 小林 猛, 日本農芸化 学会昭和 61 年度大会講演要旨集, 385 (1986)

21）谷口正之, 上平正道, 小林 猛, 安芸忠徳, 化学工学協 会第 50 年会講演要旨集, 309 (1985)

\section{「油化学」の英文名の変更について}

従来, 会誌「油化学」の英文名は「YUKAGAKU」でしたが Vol. 35, No. 2 より

IJOURNAL OF THE JAPAN OIL CHEMISTS' SOCIETY (YUKAGAKU) に変更いたしました。 なお，略号は「J. Jpn. Oil Chem. Soc.」となります。 